\title{
Diagnosis and Treatment of Dynamic External Nasal Valve Collapse: Application of Alar Batten Graft and Alar Flaring Suture
}

\author{
Ik Joon Choi, Kyoung Hun Kim, Nam Young Kim, and Myung-Chul Lee \\ Department of Otorhinolaryngology-Head and Neck Surgery, Korea Cancer Center Hospital, \\ Korea Institute of Radiological and Medical Sciences, Seoul, Korea
}

\author{
동적 외비밸브 허탈의 진단과 치료: 비익강화이식과 Alar Flaring Suture의 활용 \\ 최익준 · 김경헌 · 김남영 · 이명철 \\ 한국원자력의학원 원자력병원 이비인후-두경부외과
}

\author{
Received April 1,2016 \\ Revised May 2, 2016 \\ Accepted May 12, 2016 \\ Address for correspondence \\ Myung-Chul Lee, MD, PhD \\ Department of Otorhinolaryngology- \\ Head and Neck Surgery, \\ Korea Cancer Center Hospital, \\ Korea Institute of Radiological \\ and Medical Sciences, \\ 75 Nowon-ro, Nowon-gu, \\ Seoul 01812, Korea \\ Tel $+82-2-970-2173$ \\ Fax $+82-2-970-2450$ \\ E-mail Lmc@daum.net
}

In contrast to Caucasians, dynamic collapse of external nasal valve is not a common cause of nasal obstruction in Asians. Nevertheless, Asians with thin skin and weak nasal cartilages can have such problems. To diagnose these patients, visual inspection of external nose during forced inspiration is most important, which physicians frequently neglect. If dynamic collapse is suspected, physicians should locate the maximal site of collapse through modified cottle maneuver. The mainstay of treatment is proper reinforcement of main site of collapse with cartilage graft or various suture techniques. This article presents diagnosis and successful surgical treatments of two cases of dynamic external valve collapse with alar batten graft and alar flaring suture technique. Korean J Otorhinolaryngol-Head Neck Surg 2016;59(7):551-6

Key Words Bilateral $\cdot$ Nasal alar collapse $\cdot$ Nasal obstruction $\cdot$ Nose $\cdot$ Rhinoplasty.

\section{서 론}

비밸브(nasal valve)는 Mink에 의해서 1920년대에 처음 기 술되었으며 비강 폐쇄에 미치는 역할에 대해서는 잘 알려져 있다. ${ }^{1)}$ 비밸브는 비강의 해부학적 위치 중 가장 공기의 저항을 많이 받는 부위로 이는 비강의 입구부터 상외측비연골(upper lateral cartilage)의 미측(caudal end)까지를 이야기 한다. 이 는 다시 내비밸브(internal nasal valve)와 외비밸브(external nasal valve)로 나뉘게 된다. 내비밸브는 비중격(nasal septum), 상외측비연골의 미측, 그리고 하비갑개(inferior turbinate)의 전단(anterior end)으로 구성되며, 외비밸브는 이보다 미측 부분으로 비주(columella), 비강저(nasal floor), 하외측 비연골(lower lateral cartilage), 그리고 비익연(alar rim)으로 둘러싸여 있다. ${ }^{2)}$
비밸브에서 코막힘이 생기는 경우 병태생리학적 원인에 따 라서 정적(static)인 경우와 동적(dynamic)인 경우로 나눌 수 있다. 즉 해부학적 위치와 병태생리학적 원인에 따라서 정적, 동적 내비밸브 폐쇄와 정적, 동적 외비밸브 폐쇄로 구분된다. 이 중에서 외비밸브의 동적인 폐쇄를 일으키는 원인들로는 특 발성(idiopathic), 비성형술 기법 중 하외측비연골의 두부 절제 (cephalic resection of lower lateral cartilage)를 과하게 한 경우, 노화, 안면마비, 비성형술 후 코의 근육에 문제가 생기 는 경우 등이 있다. ${ }^{2-5)}$

인종별로 봤을 때 서양인들은 동양인에 비해서 피부가 얇 고, 비첨이 높고, 비공(nostril)이 앞뒤로 길며 가늘어서 연골 이 선천적으로 약하거나 비성형 시 연골을 심하게 절제하는 경우 비밸브의 동적인 폐쇄나 허탈이 비교적 쉽게 일어난다고 알려져 있다.,6) 반면에 동양인은 피부가 비교적 두텁고 내비밸 
브가 넓어서 동적 허탈은 서양인에 비해서 많이 보고되지 않 고 있으나, 최근 동양인들도 코의 외형이나 골격이 서구화되 고 비성형술이 많이 시행되면서 비밸브의 동적 허탈로 확인 되어 치료받는 환자가 점점 늘어가는 추세이다.,8)

저자들은 최근 외비밸브의 동적 허탈로 인해 코막힘을 호 소하는 환자 2 명을 저자들이 새롭게 시도한 alar flaring suture와 연골 이식을 통해서 성공적으로 치료하였다. 이에 이 증례들을 문헌고찰과 함께 보고하고, 새로운 기법에 대해서 소개하고자 한다.

\section{증 례}

\section{증 례 1}

32세 여자 환자가 빠르고 깊은 호흡을 할 때 심해지는 코막 힘과 코외형의 개선을 위하여 내원하였다. 병력 청취와 신체 검진 상 약간의 비중격만곡증 외에는 하비갑개 비후나 알레
르기성 비염의 소견은 없었다. 코의 외형은 정면상에서 비배 (nasal vault)에 비해서 비첨(nasal tip)이 좁았다. 측면 상에서 약간의 비혹(nasal hump)이 보이고, 비첨이 약간 낮아 보였다. 기저상(basal view)에서 외비공은 앞뒤로 길쭉하고 좁았으며, 비주의 아랫부분이 약간 넓은 소견을 보였다(Fig. $1 \mathrm{~A}, \mathrm{~B}$, and C). 비익은 강제 흡기(forced inspiration) 시에 비주와 밀착되 어 전혀 비강호흡이 불가능하였다(Fig. 2A). Modified cottle maneuver로 함몰(collapse)이 생기는 부위를 확인하였더니, 내비밸브는 문제가 없었고, 외비밸브의 문제인 것으로 확인되 었다(Fig. 2B and C). 이상의 소견으로 외비밸브의 동적 허탈 로 인한 코막힘으로 진단하고 수술을 시행하였다.

수술은 국소마취하에 개방 접근법(open approach)으로 시 행되었다. 비익강화이식(alar batten graft)으로 하외측연골과 그 미측의 연부조직을 함께 강화하기 위하여 개방 접근법 시 흔히 시행되는 변연절개술(marginal incision)이 아닌 이보다 더 미측에 절개를 하는 비익연절개술(alar rim incision)을 시
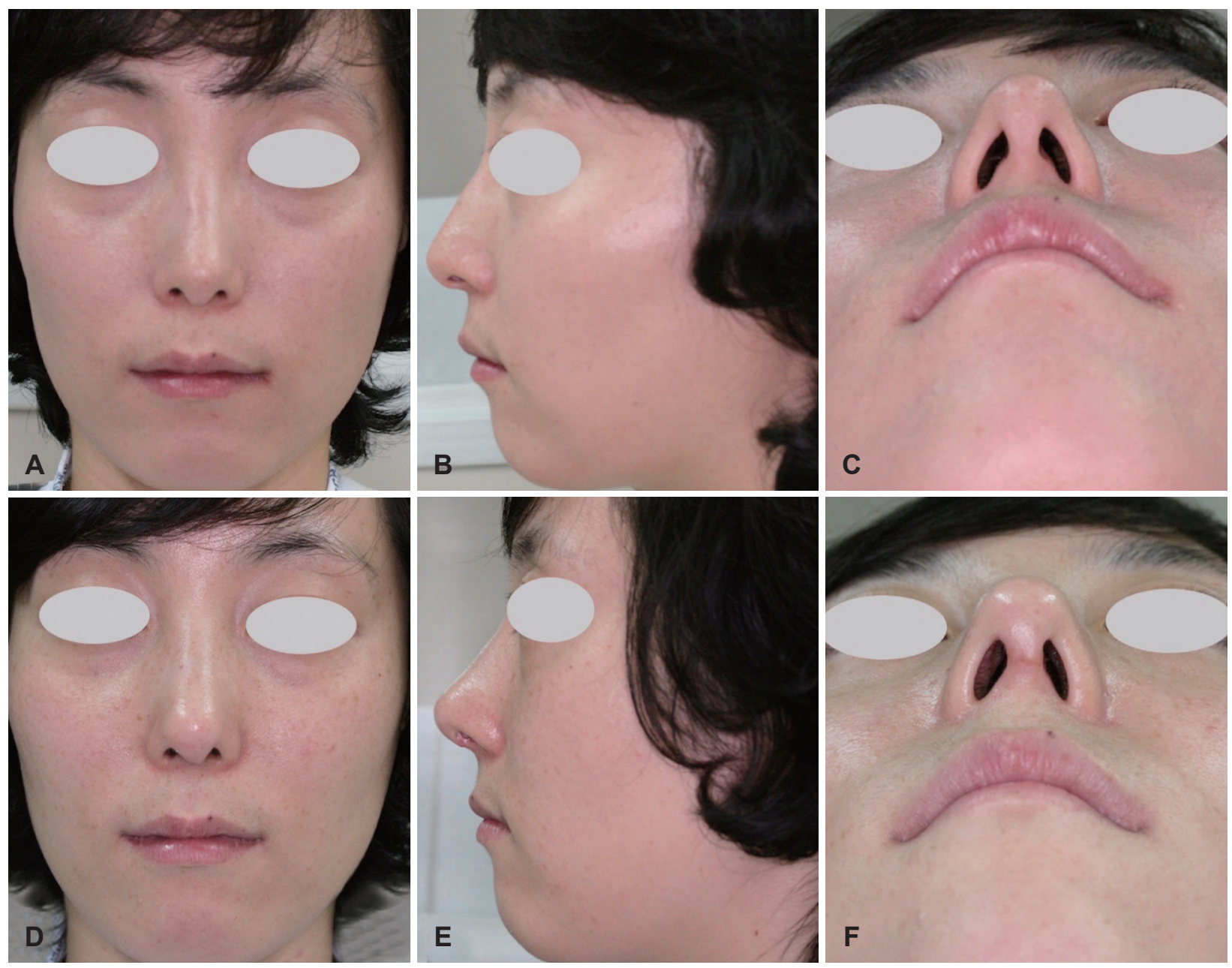

Fig. 1. Frontal view shows narrow tip compared to nasal dorsum (A). Lateral view demonstrates small hump and slightly low tip (B), and basal view shows narrow nostrils $(C)$. One-year postoperative photographs show no collapses during forced inspiration (D and $F$ ) and improved profile (E). 

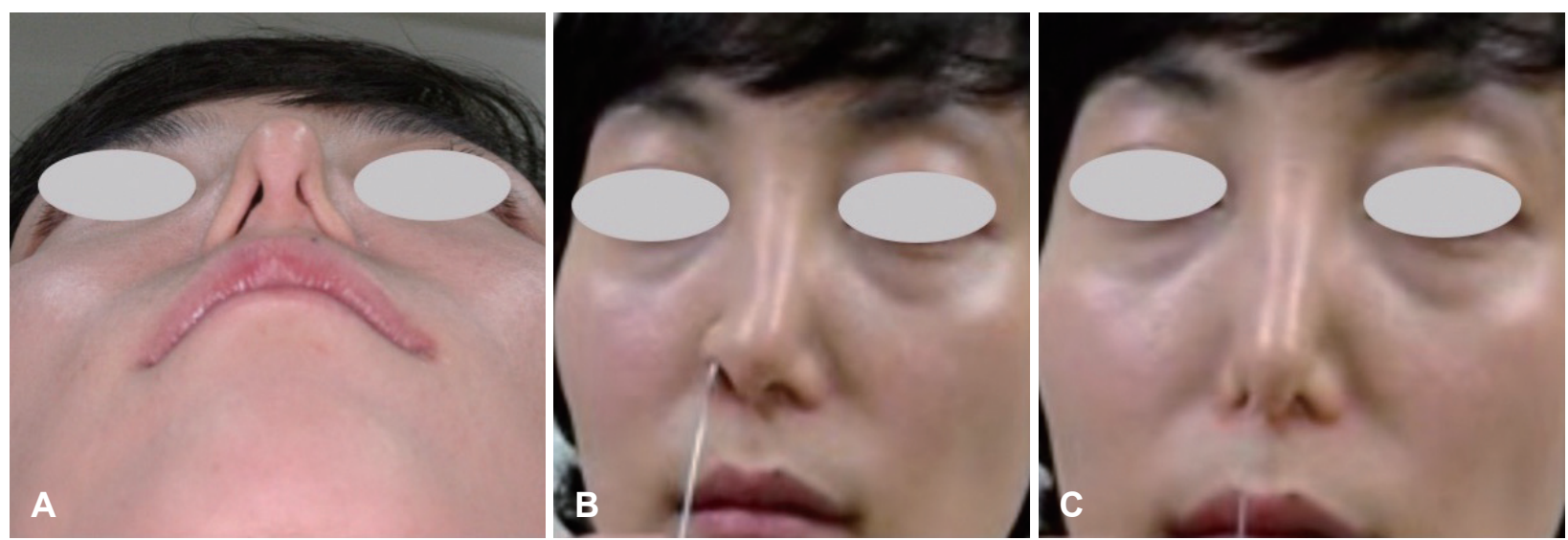

Fig. 2. Basal view shows complete obstruction of nostrils during forced inspiration (A). Modified cottle maneuver reveals a relief of right nasal obstruction during support of right external nasal valve with $Q$-tip (B) and a complete obstruction during support of right internal nasal valve $(C)$.
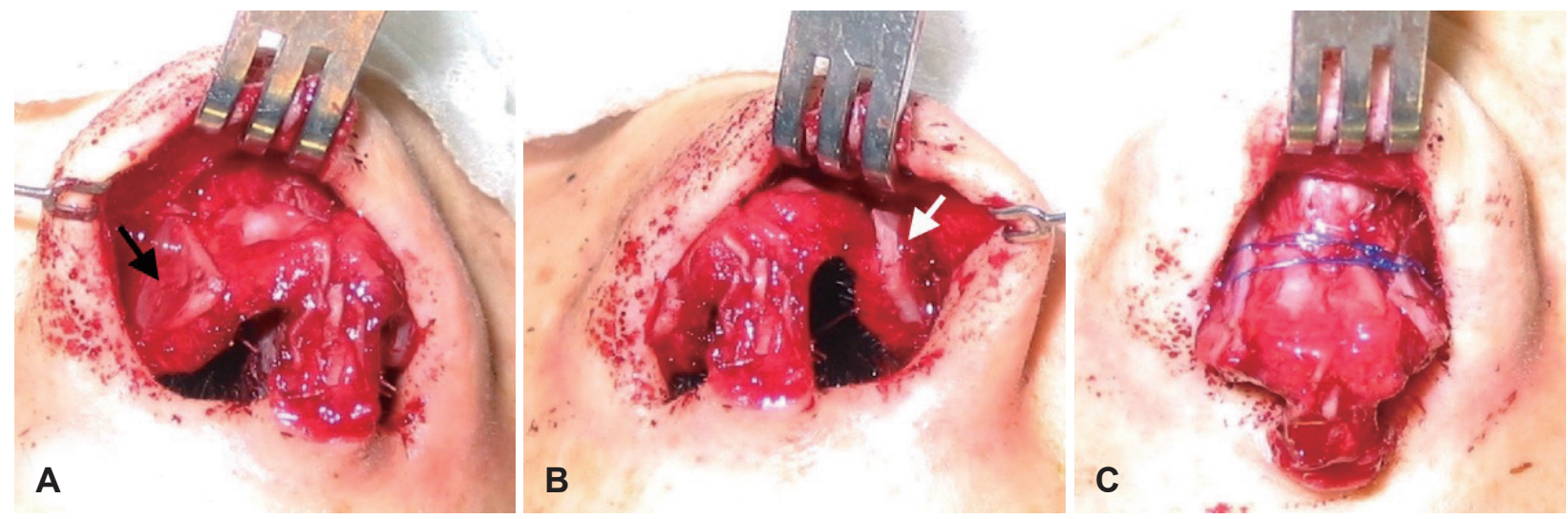

Fig. 3. Intraoperative views showing alar batten grafts and alar flaring suture. Alar batten graft was applied into the subperiosteal pocket on the pyriform aperture covering part of the lower lateral cartilage and soft tissue caudal to lower lateral cartilage which is not supported by cartilage (black and white arrow in A and B). Two alar flaring sutures were done over the dorsum to protect the collapse of alae (C).

행하였다. 비중격성형술을 하면서 비중격연골(septal cartilage)을 최대한 크게 채취하여 각종 연골이식에 사용하였다. 외비밸브의 허탈을 방지하기 위하여 비익강화이식을 시행하 였다. 이 비익강화이식은 하외측연골과 그 미측(caudal) 연부 조직 위, 그리고 이상구와(pyriform aperture) 바깥쪽의 상악 (maxilla)을 가능한 넓게 덧대 주는 모양으로 이루어졌다(Fig. $3 \mathrm{~A}$ and B). 비익강화이식편은 하외측연골과 그 미측연부조직 에 PDS 4-0을 이용하여 고정하였다. 이후 들어 놓은 피부판 (skin flap)을 덮어주고 환자에게 강제 흡기를 시켜서 비강 호 흡이 원활한지를 확인하였다. 수술 전보다는 나아졌지만 환자 가 어느 정도 코막힘을 호소하고, 비익이 허탈되는 모습을 보 여서 양쪽 비익강화이식편에서 함몰이 관찰되는 부분 사이에 비흡수성 봉합사인 Prolene 3-0을 이용하여 두 군데에서 alar flaring suture를 해 주었다(Fig. 3C). 이후 환자의 코막힘이 해 소되고, 비익의 허탈이 사라진 모습을 확인하고 이후 수술을 진행하였다. 경한 비혹을 rasping을 통하여 제거하고 비주지 주(columellar strut)와 모자이식(cap graft)으로 비첨을 융기
시키고 뾰족한 비첨의 모양을 가다듬었다. 이후 하외측비연골 의 footplate가 만져지는 부위에서 $0.5 \mathrm{~cm}$ 피부 절개를 앞뒤 로 한 후 튀어나온 footplate 연골 일부와 연부조직을 제거하 였다. 절개 부위 봉합 후 양쪽 봉합을 한 위치에서 PDS 3-0 으로 관통 봉합을 시행하여 사강(dead space)을 없애고 기저 부를 조임으로써 비주성형술을 시행하였다.

수술 후 환자는 운동시 코막힘이 해소되었고, 코 모양에도 만족하였다. 수술 1년 후에 촬영한 정면 사진에서 비첨의 모 양이 부드러워졌으며, 강제흡기 시에 비익의 허탈이 나타나 지 않는 것이 확인되었다. 측면 상에서 비혹이 사라졌고, 비 첨이 융기되고 모양이 개선되었다. 기저상에서 외비공이 넓어 졌고 비주의 기저 부분이 좁아졌음을 확인할 수 있었다(Fig. 1D, E, and F).

\section{증 례 2}

28세 여자 환자가 운동 시에 특히 심해지는 코막힘과 코모 양의 개선을 위하여 내원하였다. 병력 청취와 신체 검진 상 비 
중격만곡증, 하비갑개 비후나 알레르기성 비염의 소견은 없었 다. 코의 외형은 정면상에서 골성 비배(bony nasal vault)가 넓 어 보였고, 측면상에서는 약간의 비혹(nasal hump)이 보이고, 비근부(radix)가 낮고, 비첨이 약간 낮고 처져 보였다. 기저상 (basal view)에서 외비공은 좁았으며, 비주의 아랫부분이 약간 넓은 소견을 보였다(Fig. $4 \mathrm{~A}, \mathrm{~B}$, and C). 비익은 강제 흡기 (forced inspiration) 시에 비주와 밀착되어 비강 호흡이 전혀 불가능하였는데 왼쪽이 더 심하였다(Fig. 5A). Modified cottle maneuver로 강제 흡기를 환자에게 시키면서 허탈이 생기 는 부위를 확인하였더니, 증례 1에서와 같이 외비밸브 부분이 문제인 것으로 확인되었다. 이상의 소견으로 증례 1과 같이 외 비밸브의 동적 허탈로 인한 코막힘으로 진단하고 수술을 시
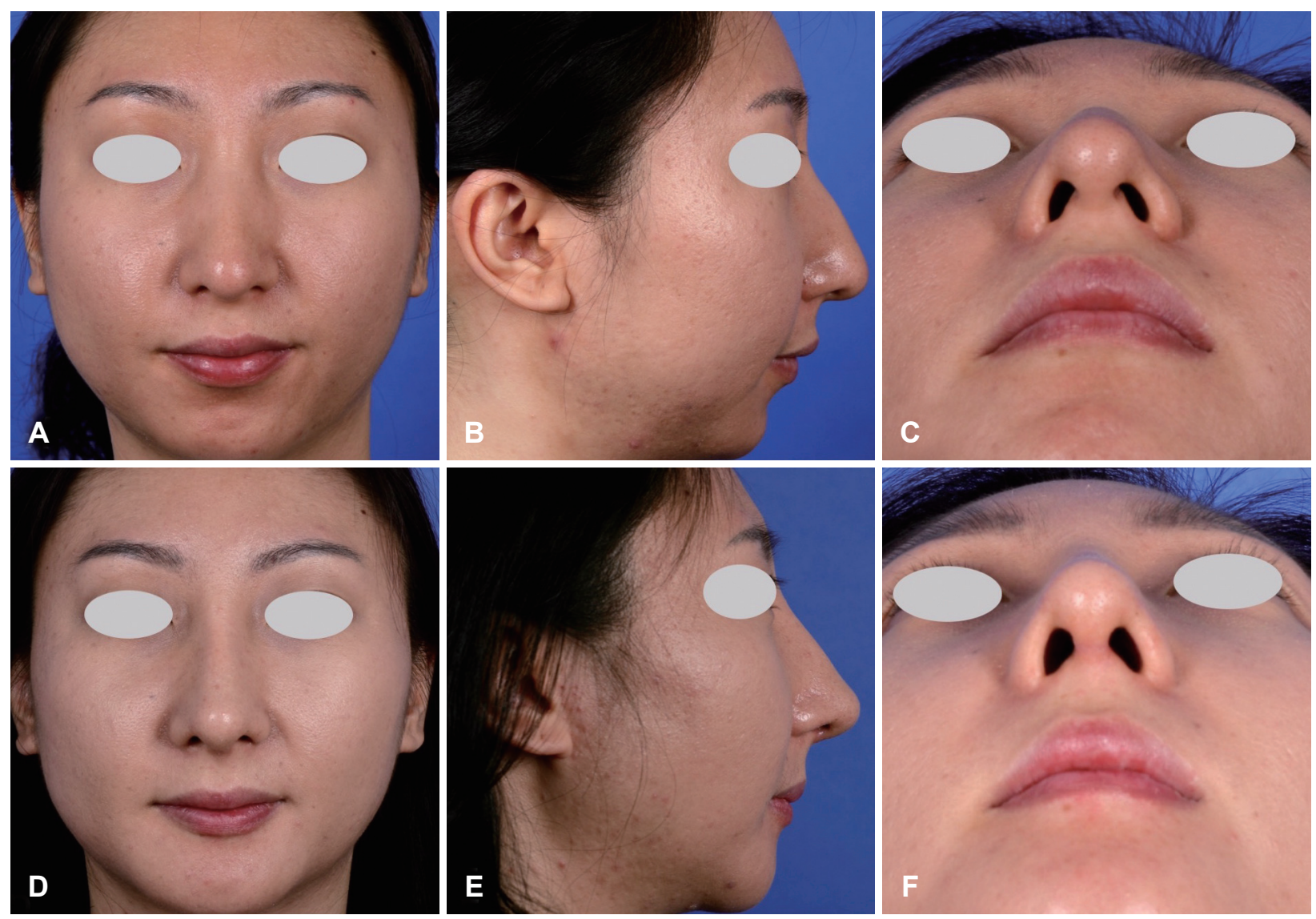

Fig. 4. Frontal view shows wide bony vault (A). Lateral view demonstrates low dorsum, small hump and slightly drooling tip (B). Basal view shows small nostrils $(C)$. One-year postoperative photographs show narrowed bony dorsum (D), no collapses during forced inspiration (D and F), and improved profile (E).

Fig. 5. Left nostril was completely obstructed during forced inspiration and right nostril was partially obstructed (A). Intraoperative photograph shows two alar flaring sutures supporting both alar batten grafts together to protect collapse of alae and goretex onlay graft on dorsum (B).
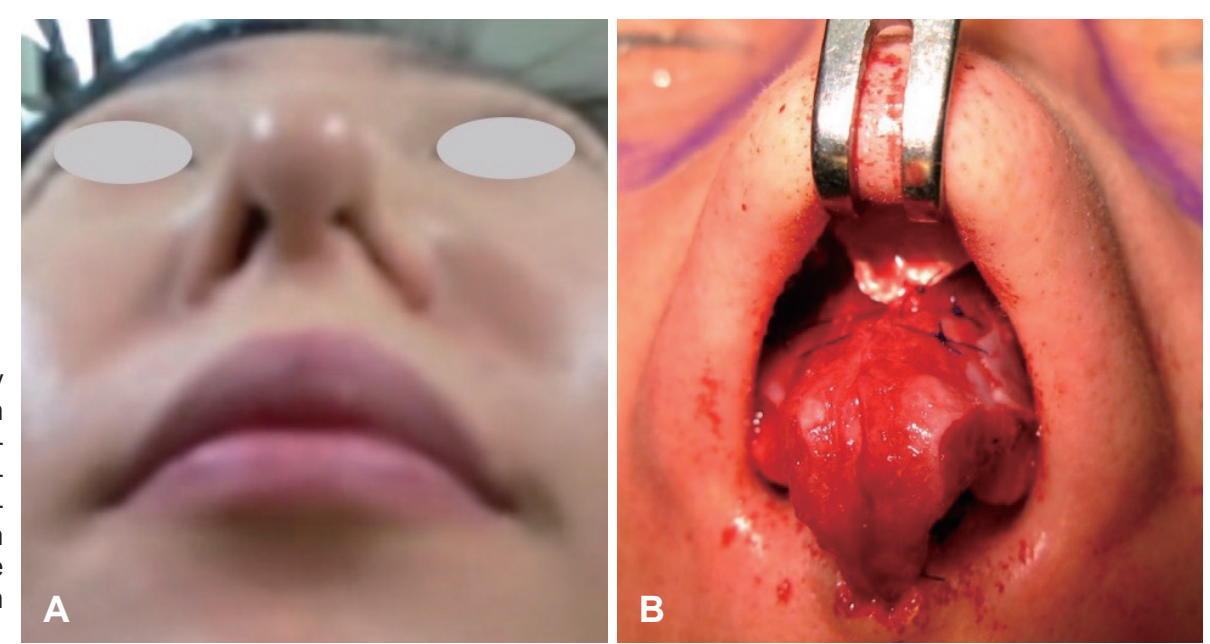
행하였다.

수술은 국소마취하에 개방 접근법(open approach)으로 시 행되었다. 비중격연골을 가지고 각종 이식에 사용하였다. 증례 1 과 같이 비익연 절개술을 시행하고, 비익강화이식을 하외측 연골과 그 미측연부조직을 강화하는 데 사용하였다. 술 중에 환자에게 강제 흡기를 시켜서 비익강화이식이 함몰되는 모양 을 파악한 후 함몰되는 부위 중심으로 연골의 모양의 변형을 가능한 안 일으키면서 허탈이 방지되는 부위에 적당한 강도 로 alar flaring suture를 시행하였다(Fig. 5B). 수술 중에 허 탈이 더 이상 일어나지 않는 것을 확인한 후에 이후 수술을 진행하였다. 비중격연장이식(septal extension graft)과 모자 이식을 통하여 비첨의 융기와 회전(rotation)을 시도하였고, 비혹제거 후 내외측 절골술로 골성비배를 좁히고, 고어텍스 를 이용하여 융비술(dorsal augmentation)을 시행하였다. 비 주성형술을 통해 비주의 기저 부분을 좁게 만든 후 수술을 종료하였다.

수술 10 일 후부터 코막힘이 호전되었고, 1 년이 지나서 한 마 지막 검진에서도 코막힘의 호소는 없었다. 수술 후 1년째에 촬 영한 사진에서 강제 흡기 시에 비익의 함몰은 관찰되지 않았 고, 외비공이 넓어진 것을 확인할 수 있었다. 측면에서도 비첨 이 융기되고 회전되어서 비순각이 넓어졌으며, 비배도 융기되 었고 환자는 본인의 코 외형에 만족하였다(Fig. 4D, E, and F).

\section{고 찰}

본 연구에서 저자들은 alar flaring suture와 비익강화이식 을 통하여 외비밸브 허탈을 성공적으로 치료하였다.

비밸브는 비강의 공기흐름을 결정하는 가장 중요한 부위이 다. 한국인의 경우 내비밸브의 각도가 서양인보다 넓고, 비배, 비익 등을 덮고 있는 피부와 연부 조직이 두꺼워 비밸브의 문 제가 많지 않다고 알려져 있다. 그래서 코막힘 환자들을 진찰 하고 치료할 때 이러한 비밸브의 문제를 크게 중요하게 생각 하지 않아 왔던 측면이 있고 이에 대한 연구가 많지 않았다. 하지만 한국인들 중에도 피부와 연부조직이 얇고 연골이 약 한 경우, 또 비성형수술 시 연골의 절제가 과도하여 연골의 지지가 약해진 경우 등에서는 비밸브의 허탈이 생겨서 코막 힘이 유발되는 경우가 있다. ${ }^{78)}$

이러한 비밸브의 문제를 진단하는 데 가장 중요한 것은 환 자에게 강제 흡기를 시키면서 외형을 살펴보는 것이다. 이러 한 밸브의 문제를 가진 환자들은 운동시나 심호흡 시에 코막 힘을 호소하는 경우가 많은데 외래 진찰 시에 비경(nasal speculum)이나 비내시경(nasal endoscope)을 써서 비강 내의 상태 를 확인하려고 하면 이러한 비밸브의 문제를 확인하기가 어
렵다. 비경을 쓰게 되면 외비밸브를 들어 버리기 때문에 문제 를 인지할 수가 없고, 비내시경을 쓰면 내비밸브의 각도를 볼 수 있기는 하지만 외비밸브를 지나가버리기 때문에 외비밸브 의 문제를 확인할 수가 없다.

강제 흡기를 시키면서 외형을 밨을 때 허탈이 일어나는 것 을 확인했다면 치료를 위해서 이러한 허탈이 내비밸브에서 일 어나는지 외비밸브에서 일어나는지 확인하는 작업이 필요하 다. 이때 가장 적당한 진단방법이 modified cottle maneuver 이다." 이 방법은 비강 안에서 Q-tip 끝으로 허탈이 일어나는 부위를 지탱했을 때 환자의 비강호흡이 호전되는지를 직접 확 인하는 것이다. 두 증례 모두에서 Q-tip 끝을 외비밸브만을 지탱했을 때 강제 흡기 시 코막힘이 호전되었고, 내비밸브만을 지탱했을 때는 외비밸브의 허탈로 인해서 외비공이 막히면서 코막힘을 호소하는 현상을 보여서 외비밸브의 동적인 허탈에 의한 코막힘이라고 진단을 내릴 수 있었다(Fig. 2B and C).

외비밸브의 허탈을 교정하기 위한 수술법에는 비익연이식 (alar rim graft), 비익강화이식, 그리고 외측현수봉합(lateral suspension suture) 등이 있다. ${ }^{4)}$ 외형의 교정과 같이 할 수 있 는 방법으로 가장 대표적으로 쓰여지는 방법은 비익강화이 식이다. 비익강화이식은 비내 또는 비외접근법으로 시술하게 되는데, 기본적으로는 이식할 연골편을 하외측비연골의 미 측 연골이 없는 부분에서 이상구의 외연에 걸친 부위에 이식 하는 것이다. ${ }^{4,6)}$ 이 이식법은 허탈되는 중심부위(epicenter)의 위치나 크기에 따라 이식편의 크기나 위치를 조절해서 이식해 야 좋은 결과를 얻을 수 있다. 대개 연골은 약간의 굴곡이 있 는 것이 좋은데 비중격연골이나 이개 연골(conchal cartilage) 을 사용하게 된다. 이러한 비익강화이식은 Toriumi 등이 다른 연구자들에 의해서 많은 연구에서 좋은 결과를 얻을 수 있는 것으로 보고되고 있지만 국내에서는 아직 보고가 많지 않은 상황이다.

본 증례에서도 비익강화이식을 시행하였는데 채취된 비중 격연골의 크기는 적당하였으나 두께가 얇아서 강도(strength)가 약하였다. 비익강화이식을 시행한 후 피부판을 임시로 덮고 고정한 후 환자에게 강제 흡기를 시켰을 때 수술 전보 다는 호전되었지만 허탈이 남아 있어 코막힘을 호소하였다. 이에 alar flaring suture를 양측 비익강화이식을 연결해서 띄 워주는(flaring) 방식으로 시행하고 환자에게 강제 흡기를 시 켰을 때 허탈이 방지되는 것을 확인하고, 밸브에 대한 수술 은 마무리하였다. 기존에 alar flaring suture는 내비밸브의 정적인 허탈, 즉 내비밸브의 각도가 좁을 때 각도를 넓혀주기 위해서 양측 상외측비연골(upper lateral cartilage, upper ala) 을 봉합을 통해서 띄워주는(flaring) 방식으로 시행한다고 알 려져 있었다. 하지만 본 연구에서는 기존의 alar flaring suture 
와 방식은 같지만 alar flaring suture를 양측 상외측비연골 이 아닌 양측 비익강화이식을 연결하는 봉합을 하는 데 사용 하여 외비밸브의 동적인 함몰을 방지할 수 있다는 것을 확인 하였다.

저자들이 시도한 alar flaring suture를 시행할 때 주의할 점 은 첫째, 하외측비연골과 그 미측의 연골이 없는 연부조직에 바로 봉합을 시도하면 기존의 연골이나 연부조직이 얇고 약 해서 봉합하기 위해 힘을 줄 때 양쪽 비익이 들려 비배 부분 이 넓어지거나 연골 자체의 변형으로 코의 외형에 변화가 올 수 있다는 것이다. 가능하면 비익강화이식을 먼저 시행하여 약한 비익 부분을 강화한 다음 양측 비익강화이식 사이에 봉 합을 해야 변형을 안 만들면서 적당한 힘으로 허탈이 안 일어 나게 힘을 줘서 봉합을 마무리할 수 있다. 둘째, 비흡수성 봉 합사를 사용하는 것이 반영구적인 결과를 보여줄 수 있다. 셋 째, 경험이 쌓이면 전신마취하에서도 적당한 힘으로 비익의 모양을 유지하면서 허탈이 안 생길 정도의 강도로 봉합을 할 수 있겠지만, 가능하면 국소마취하에서 시행하여 수술 중에 환자에게 강제 흡기를 시켜서 허탈이 방지되는지 확인하는 것 이 좋다.

본 증례들은 모두 운동이나 깊은 호흡 시에 외비밸브가 허 탈 되어 코막힘이 생겼던 경우이다. 이러한 외비밸브의 동적 인 허탈에 의한 코막힘은 한국인에서도 발생할 수 있으므로 코막힘 환자를 진찰할 때 감별진단으로 반드시 고려되어야 한다. 또한 정확한 진단과 위치 확인이 가장 중요하고, 이에 따
른 여러 수술방법을 숙지하고 응용할 수 있어야 효과적으로 치료할 수 있다. 수술 시 비익강화이식만으로 효과가 불충분 할 때는 본 증례에서처럼 alar flaring suture를 보조적으로 사용하면 좋은 효과를 기대할 수 있을 것으로 생각한다.

\section{REFERENCES}

1) Goode RL. Surgery of the incompetent nasal valve. Laryngoscope 1985;95(5):546-55.

2) Fischer H, Gubisch W. Nasal valves--importance and surgical procedures. Facial Plast Surg 2006;22(4):266-80.

3) Spielmann PM, White PS, Hussain SS. Surgical techniques for the treatment of nasal valve collapse: a systematic review. Laryngoscope 2009;119(7):1281-90.

4) Schlosser RJ, Park SS. Functional nasal surgery. Otolaryngol Clin North Am 1999;32(1):37-51.

5) Constantian MB. The incompetent external nasal valve: pathophysiology and treatment in primary and secondary rhinoplasty. Plast Reconstr Surg 1994;93(5):919-31; discussion 932-3.

6) Ballert JA, Park SS. Functional rhinoplasty: treatment of the dysfunctional nasal sidewall. Facial Plast Surg 2006;22(1):49-54.

7) Jin HR, Mo JH. Surgical correction of dynamic nasal valve collapse. Korean J Otolaryngol-Head Neck Surg 2009;52(2):175-9.

8) Jung DH, Kim YJ, Choi WS, Han CJ, Jang TY. Treatment of the nasal valve stenosis. Korean J Otolaryngol-Head Neck Surg 1999;42(6): 727-33.

9) Fung E, Hong P, Moore C, Taylor SM. The effectiveness of modified cottle maneuver in predicting outcomes in functional rhinoplasty. Plast Surg Int 2014;2014:618313.

10) Toriumi DM, Josen J, Weinberger M, Tardy ME Jr. Use of alar batten grafts for correction of nasal valve collapse. Arch Otolaryngol Head Neck Surg 1997;123(8):802-8. 